\title{
German hostage was saving Iraq digs
}

Susanne Osthoff- the German archaeologist kidnapped in Iraq last month - was a lone force against looters, according to researchers in the field. They say that she was fighting to protect archaeological sites from the plundering that has been rife in the postwar chaos.

Field work in Iraq had to be abandoned after British and US troops invaded two years ago. And although the looting of the Iraqi National Museum in April 2003 received widespread media attention, the continuing loss of artefacts from more distant field sites is less appreciated. Osthoff was being "heroic" in trying to bring public attention to the crimes, says Michael Müller-Karpe, an archaeologist at the Roman-Germanic Central Museum in Mainz, Germany.

Hundreds of sites are being looted by ordinary citizens trying to make a quick profit, says Elizabeth Stone, an archaeologist at Stony Brook University in Long Island, New York. In a way, this widespread ransacking is worse than the looting of the museum, because the antiques being removed have never been catalogued, she says.

At first, little action was taken to protect the remote sites. But in the past few months about 1,000 Iraqi police have been deployed in the Dhi Qar province in the southeast of the country to look after them. "This has begun to have an effect," Stone says. She has started to map the sites using satel lite imagery, and hopes to make pictures available to Iraqi officials in Baghdad and in Nasiriya, the province's capital.

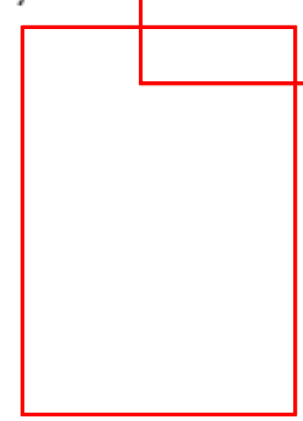

In the field: archaeologist Susanne Osthoff (left) was trying to publicise the looting of digs in Iraq before she was kidnapped late lastmonth.

Osthoff studied archaeology at the University of Munich, and in the late 1980 s worked at a site in Isin, south of Baghdad. Now that field work is so dangerous, "a whole generation of students has not been involved in Mesopotamian archaeology," laments Joan Maclver of the British School of Archaeology in Iraq, based in London.

Joanne Farchakh Bajjaly, a Beirut-based archaeologist, met Osthoff in April 2003 in Baghdad, when Osthoff was on her way to Isin with a German television crew to report on the looting problem. Farchakh Bajjaly describes her as "a very courageous, strong woman", saying such attributes are necessary for tackling a strong, well-organized mafia of antiques traders. Osthoff was aided by her fluent Arabic and her connections with a local tribe that helped to protect her, says Farchakh Bajjaly.

Osthoff's kidnapping has raised the profile of the problem - but at a very high price, say archaeologists. As Nature went to press, she was still being kept hostage.

Andreas von Bubnoff

\section{Cowrie study strikes a blow for traditional taxonomy}

WASHINGTON DC

Itmay be too early to use a technology called DNA barcoding to speed the identification of species, says an analysis released last week.

DNA barcoding involves collecting and comparing genetic sequences from many species. Some proponents believe that bypassing the slower techniques of traditional taxonomy will identify unknown species and categorize the world's biodiversity more quickly. Buta study by Christopher Meyer and Gustav Paulay of the University of Florida in Gainesville shows that barcoding works well only for species that are already much studied.

The scientists examined a database of marine snails called cowries, which have been studied since the nineteenthcentury because of their valuable shells. By analysing the sequence of a gene called cytochrome oxidase 1 from a cowrie specimen, then comparingit with the entire database of genetic sequences, the scientists correctly identified cow rie species with less than $4 \%$ error.

But Meyer and Paulay hit trouble when they reconfigured their database to examine how barcoding works for less well studied groups. They used a method pioneered by other barcoding scientists to pinpoint new species. This method compares diversity among members of the same species and diversity between different species.
They showed that in species that have been less studied, the barcoding method misidentified unknown specimens up to $20 \%$ of the time (C. P. Meyer and G. Paulay PLOS Biol. 3, e422; 2005).

Some scientists view the high success rate for known species as a triumph for barcoding. They also say that the field is very young and is still working out the best waystodeal with organisms about which there is little information. "This was a very ambitious test for the technique," 


\section{Chairman explains Europe's research council}

\begin{abstract}
The European Research Council (ERC), to be launched in 2007, will be the first Europe-wide granting agency for basic research. On 5 December, its Scientific Council announced the election of molecular biologist Fotis Kafatos as chairman.
\end{abstract}

Alison Abbott takes this opportunity to quiz

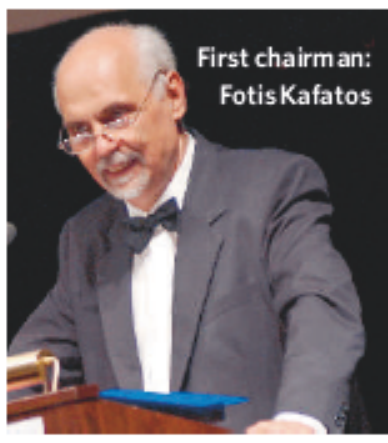

create and supervise an efficient, flexible and responsive structure for our calls for proposals and the peer-review system.

Annual funding of $€ 1.5$ billion (US $\$ 1.8$ billion) has been requested for the ERC, but interest among researchers is so high that huge oversubscription is Kafatos, a lab chief at Imperial College London and formerly director of the European Molecular Biology Laboratory in Heidelberg, Germany.

The ERC is designed to support the best basic research in Europe based on an independent peer-review system. When will it start distributing money? The political process for approving the seventh of the European Union's five-year Framework programmes for research will run through next year. The Framework's plan to create an ERCis secure, but it will have a legal basis only when this process is completed. We will be using this time for intensive preparatory work, so we should be ready to issue our first call for proposals very soon after that.

\section{What is the role of the Scientific Council} within the ERC structure?

The Scientific Council is the supreme body, and the agency will operate under our guidance. We will be assisted by a secretarygeneral who will have the experience to predicted. How will you structure your calls so as to limit subscriptions? The ERC will cover all fields of scholarship. One of our key tasks is to work out how to structure calls in a way that does not compromise this basic tenet. At the moment, no option is excluded. We will also think about a two-stage application procedure to relieve oversubscription.

How will the ERC peer-review system operate?

This is also something that we have to work out in detail. Certainly, it will take into account the international best practice.

What would happen if the Framework programme were to be squeezed hard during political negotiations, and the ERC given less money than requested? It would not be worth establishing the ERC if it were poorly endowed - the funding has to be sufficient for it to work properly and make a difference. Personally, I think the absolute minimum would be $€ 1$ billion per year.

\section{IMAGE UNAVAILABLE FOR COPYRIGHT REASONS}

DNAbarcoding identifies well known species such as this chestnut cowrie, but it comes a cropper on others.

says David Schindel, executive secretary of the Consortium for the Barcode of Life, a group of 93 barcoding practitioners hosted by the Smithsonian Institution in Washington DC. "Chris and
Gustav have done a very good job of presenting the possible procedural problems that barcoding willencounter, and we are working out protocols for more sophisticated analysis of barcode data," says Schindel. Meyer stresses that the concept of barcoding remains solid. Indeed, his museum is a member of the barcoding consortium. But, hesays, his study shows that barcoding will not supplant traditional taxonomy. Meyer says he hopes his study will help convince funding agencies to supportold-fashioned taxonomy - a discipline that seems to be slowly disappearing - as well as DNA barcoding. Erika Check 